Tạp chí Các Khoa học về Trái Đất, 38 (1), 108-117

\begin{tabular}{c} 
Viện Hàn lâm Khoa học và Công nghệ Việt Nam \\
Tạp chí Các Khoa học về Trái Đất \\
(VAST) \\
Website: http://www.vjs.ac.vn/index.php/jse \\
\hline
\end{tabular}

\title{
Đặc điểm tướng trầm tích và địa chất công trình các thành tạo Holocen khu vực ven biển huyện Tiên Lãng, Thành phố Hải Phòng
}

Vũ Văn Lợi

Công ty Cổ phần Tu vấn Thiết kế công trình xây dựng Hải Phòng

Chấp nhận đăng: 12 - 2 - 2016

ABSTRACT

Sedimentary facies and engineering geological characteristics of Holocene deposits in the coastal area

of Tien Lang district, Hai Phong city

\begin{abstract}
Infrastructural construction has recently been an important issue in the coastal zone of Tien Lang district, Hai Phong city. The area is characterized by soft layers of Holocene deposits, causing difficulties to engineering construction and land use planning of the area. Geological investigation has defined 8 facies and subfacies of Holocene deposits in the coastal area of Tien Lang district, along with their sedimentary and engineering geological characteristics. In the view point of engineering geology, these deposits are almost soft soil layers. Their significant thicknesses and wide area of distribution, require specific consideration in construction design and ground reinforcement to ensure the longterm stability of engineering structures.
\end{abstract}

Keywords: Sedimentary, Sedimentary facies, Engineering geological, Holocene, Tien Lang.

(C)2016 Vietnam Academy of Science and Technology

\section{Mở đầu}

Khai thác và sử dụng quỹ đất có hiệu quả các bãi bồi ven biển là một trong những mục tiêu hàng đầu phát triển kinh tế - xã hội thành phố Hải Phòng giai đoạn 2015-2025. Huyện Tiên Lãng là một trong bốn quận huyện nằm sát bờ biển của thành phố Hải Phòng, có tọa độ địa lý từ $20^{\circ} 30^{\prime}$ đến $20^{\circ} 43^{\prime}$ vĩ độ bắc và từ $106^{\circ} 34^{\prime}$ dến $106^{\circ} 52^{\prime}$ kinh độ đông. Khu vực nghiên cứu thuộc vùng cửa sông Văn Úc - Thái Bình, kéo dài từ bán đảo Đồ Sơn ở phía đông bắc và đến cửa Diêm Điền ở phía tây nam được xác định từ bờ đê quốc gia, cắt qua các cửa sông đến độ sâu 20-23m nước (hình 1).

Đây là khu vực ven biển có tốc độ bồi tụ khá

Email: vuvanloi36@gmail.com mạnh, xét trong giai đoạn 1975 đến 2010 xu hướng bồi tụ vẫn thắng thế tuyệt đối theo các bậc địa hình khác nhau tính đến độ sâu $20 \mathrm{~m}$ nước đều được mở rộng và lấn ra biển, trung bình $18,68 \mathrm{~m} /$ năm, đây là một trong những yếu tố thuận lợi để tiến hành quy hoạch lấn biển (Nguyễn Đức Cự, 2011). Bên cạnh đó, còn có những yếu tố bất lợi, như tác động của hoạt động nhân sinh, nước biển dâng do bão, nước dâng do sóng và mực nước cực trị trong bão (nếu xét tần suất $1 \%$ tức hồi ký 100 năm mực nước cực trị đạt từ $494 \mathrm{~cm}$ tới $540 \mathrm{~cm}$, vượt hầu hết cao trình đê biển khoảng 5,5m) gây lụt lội, vỡ đê, các hiện tượng xói lở, biến dạng nền đất yếu (Nguyen Xuan Hien, et al., 2010; Hoang Trung Thanh, Pham Van Huan, 2009). Những yếu tố đó chưa được đánh giá đầy đủ, do vậy, việc nghiên cứu đặc điểm, quy luật phân bố nền đất yếu thuộc thành tạo Holocen tại các khu vực này còn nhiều hạn chế. 
V.V. Lợi/Tạp chí Các Khoa học về Trái Đất, Tập 38 (2016)

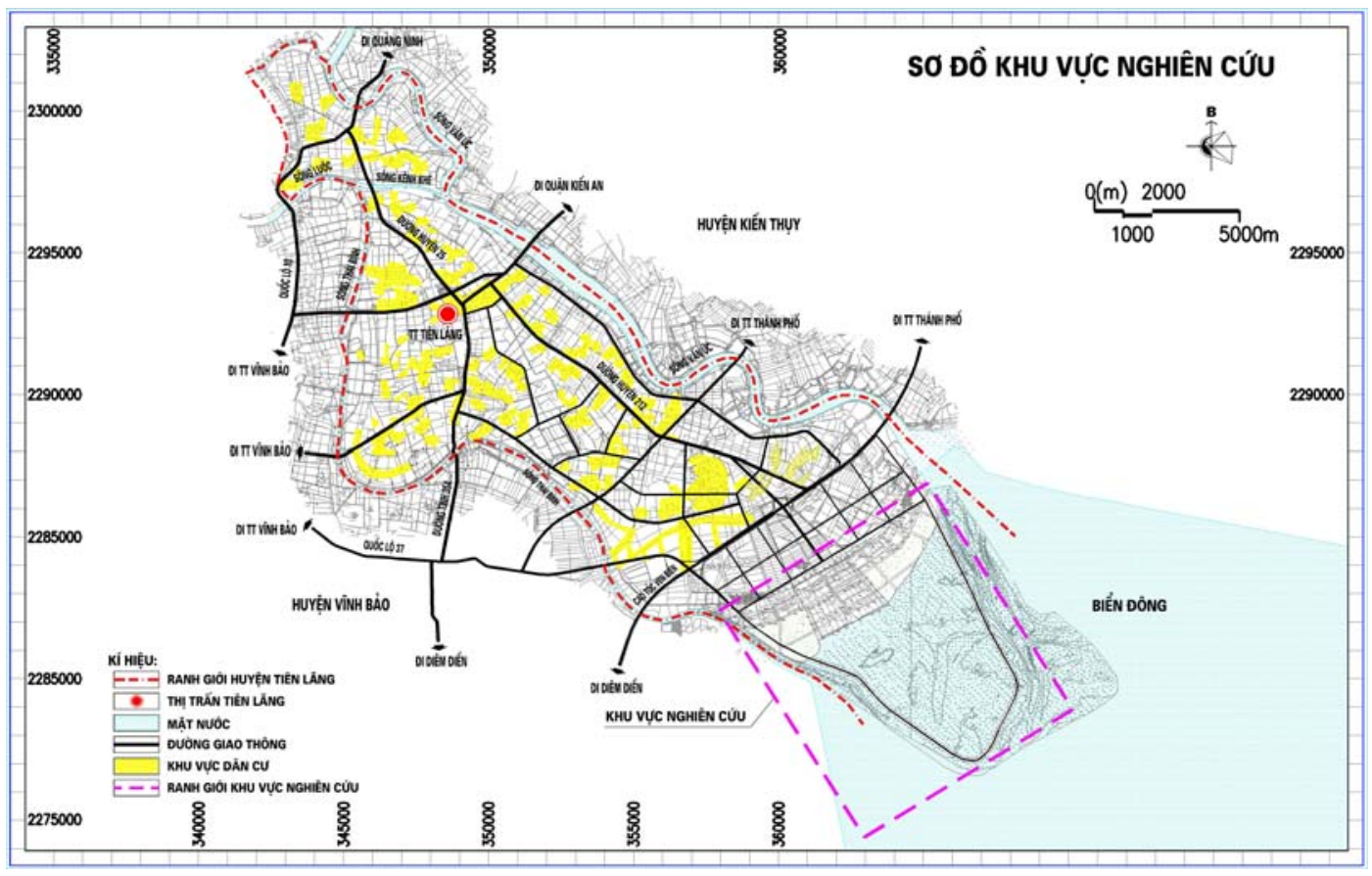

Hình 1. Sơ đồ khu vực nghiên cứu

Hiện nay, công tác nghiên cứu lập quy hoạch vùng bãi bồi ven biển huyện Tiên Lãng đã và được thực hiện. Đây là điểm mốc quan trọng, đặt nền móng cho các giai đoạn phát triển tiếp theo, nhằm phát triển cơ sở hạ tầng, phục vụ tăng trưởng kinh tế vùng trọng điểm Hà Nội, Hải Phòng và Quảng Ninh. Do đó, nghiên cứu đặc điểm tướng trầm tích và địa chất công trình các thành tạo Holocen khu vực ven biển huyện Tiên Lãng là nhiệm vụ hàng đầu, có vai trò quan trọng và cấp thiết.

\section{Khái quát khu vực nghiên cứu}

Khu vực nghiên cứu là vùng ven biển huyện Tiên Lãng, thành phố Hải Phòng, bao gồm toàn bộ khu vực bãi bồi ven biển nằm giữa hai cửa sông Văn Úc và sông Thái Bình với tổng diện tích 4.600ha, chiều dài đường bờ $9,5 \mathrm{~km}$ đi qua bốn xã Tây Hưng, Đông Hưng, Tiên Hưng, Vinh Quang (hình 2).

\section{1. Đặc điểm địa hình, địa mạo}

Theo cao độ mực nước thủy triều dâng, khu vực nghiên cứu chia thành đới trên triều, đới gian triều và đới dưới triều.
- Đới trên triều: Bãi bồi nằm hoàn toàn trên cạn cao độ từ $3,0 \mathrm{~m}$ trở lên (theo cốt lục địa), được bao bởi đê Quốc gia, các bờ đắp ngăn với các bãi bồi phía biển, diện tích khoảng 200 ha. Đây là nơi hoạt động nhân sinh diễn ra khá mạnh, chiếm tới 80$90 \%$ diện tích là khu sinh thái, nhà tạm, đào ao nuôi trồng thủy hải sản.

- Đới gian triều: Bãi bồi nổi cao với nhiều cồn cát thể hiện rõ hình thái của cửa sông châu thổ, ngoài ra còn có các bãi bồi khá bằng phẳng tạo thành bãi bồi phẳng và nhiều cồn cát được chia cắt bởi các bề mặt địa hình thấp hơn nghiêng về phía biển, diện tích khoảng 2.400 ha. Bãi gian triều được chia thành: bãi triều cao (tính từ cao độ từ mực nước trung bình $1,86 \mathrm{~m}$ đến cao độ $3,0 \mathrm{~m}$ ) diện tích khoảng 400 ha, hoạt động nhân sinh diễn ra tương đối mạnh chiếm tới 40-50\% diện nuôi trồng thủy hải sản. Bãi triều thấp (cao độ từ $1,86 \mathrm{~m}$ đến 0,0m hải đồ) diện tích khoảng 2.000 ha, hoạt động nhân sinh giảm hẳn, chủ yếu là các bãi nuôi ngao, sò, ở một số nơi có các bãi và cồn cát nổi cao, phân bố ở hai bên cửa sông Văn Úc, Thái Bình và khu vực giữa vùng nghiên cứu. 
Tạp chí Các Khoa học về Trái Đất, 38 (1), 108-117

- Đới dưới triều: Tính từ cao độ từ $0,0 \mathrm{~m}$ hải đồ trở xuống, đây là khu vực bãi bồi tương đối bằng phẳng thường xuyên ngập nước, dốc về phía biển, diện tích khoảng 2.000 ha.

\section{2. Đặc điểm địa chất}

Trong khu vực nghiên cứu các thành tạo Holocen bao gồm hai hệ tầng: Hệ tầng Hải Hưng $\left(\mathrm{Q}_{2}{ }^{1-2} h h\right)$ và Hệ tầng Thái Bình $\left(\mathrm{Q}_{2}{ }^{3} t b\right)$. Hệ tầng Hải Hưng phân bố trải rộng khắp khu vực nghiên cứu, chiều dày từ $3,5 \mathrm{~m}$ đến $23,0 \mathrm{~m}$, nguồn gốc biển. Hệ tầng Thái Bình phân bố khắp khu vực nghiên cứu, trầm tích có nguồn gốc hỗn hợp sông biển, chiều dày từ $7,0-10,0 \mathrm{~m}$ đến $15,0-17,0 \mathrm{~m}$; nguồn gốc biển, chiều dày từ $3,0-5,0 \mathrm{~m}$ đến 10,0 12,8m (Nguyễn Đức Đại, 1996; Ngô Quang Toàn, 1995).

\subsection{Chế độ thủy triều}

Đây là vùng có chế độ nhật triều thuần nhất với biên độ dao động thuộc loại thủy triều lớn ở Việt Nam. Tại khu vực nghiên cứu, biên độ triều khi mực nước lớn nhất (spring tide) đạt tới 4,25m. Khi mực nước nhỏ nhất (neap tide) tại điểm xa nhất của tuyến đê dự kiến quy hoạch, do hoạt động khai thác cát nên độ sâu mực nước dao động từ $1,50 \mathrm{~m}$ đến 3,20m, có chỗ lên tới 4,00-5,50m (Nguyễn Đức Cự, 2011).

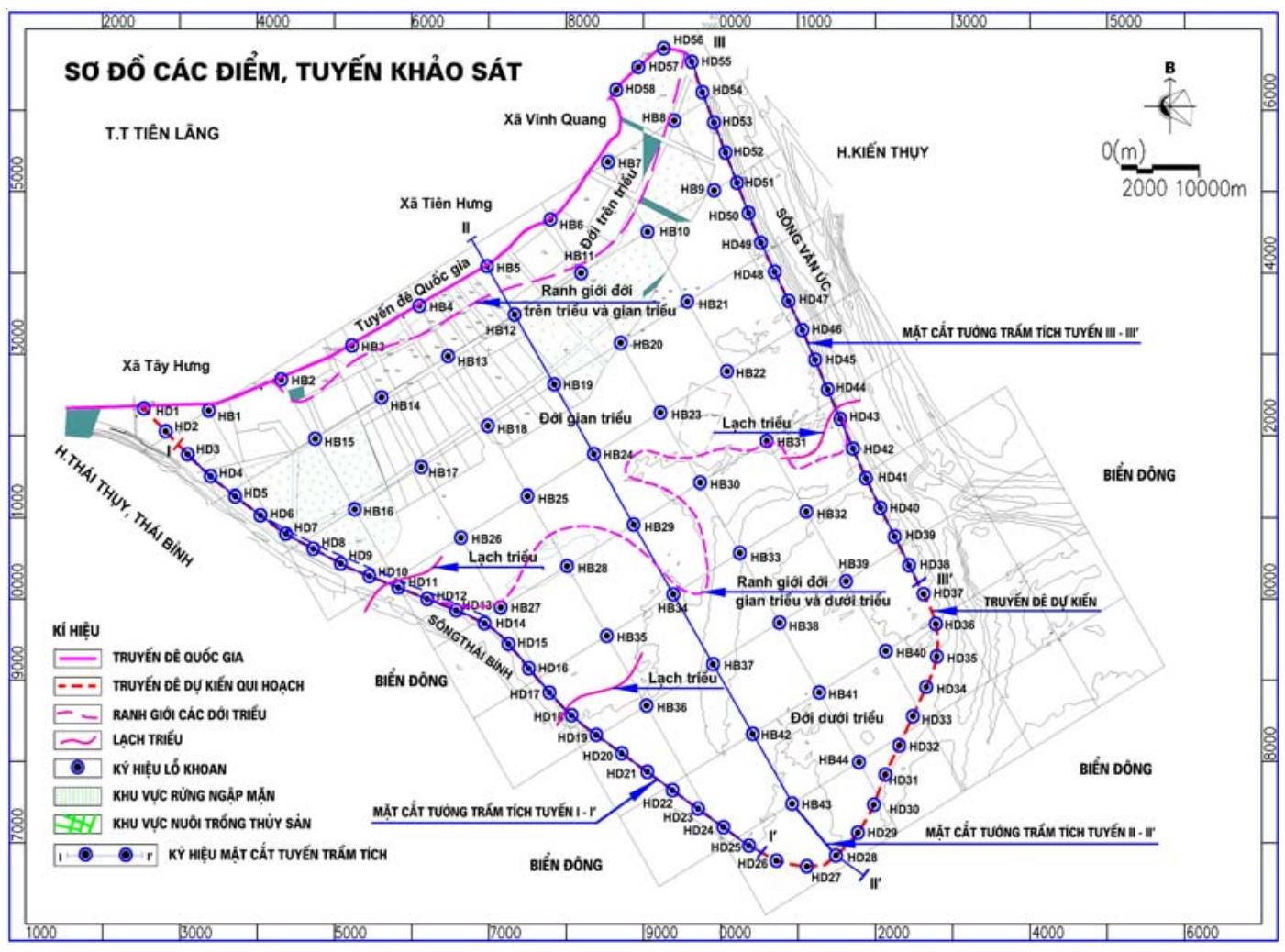

Hình 2. Sơ đồ các lỗ khoan, điểm và các tuyến khảo sát trong khu vực nghiên cứu

\section{Co' sở tài liệu và phương pháp nghiên cứu}

\subsection{Co' sở tài liệu}

Bài báo được hoàn thành trên cơ sở tổng hợp, xử lý các tài liệu địa chất vùng nghiên cứu, kết hợp với kết quả khảo sát địa chất và địa chất công trình khu vực ven biển huyện Tiên Lãng, thành phố Hải Phòng do Liên danh nhà thầu khảo sát Công ty Cổ phần tư vấn thiết kế CTXD Hải Phòng và Công ty Cổ phần tư vấn xây dựng Hoàng Hà mà tác giả là 


\section{V.V. Lợi/Tạp chí Các Khoa học về Trái Đất, Tập 38 (2016)}

thành viên tham gia thực hiện. Khối lượng công tác khảo sát được trình bày ở (bảng 1 ).

Bảng 1. Khối lượng công tác khảo sát địa chất công trình khu vực nghiên cứu

\begin{tabular}{lll}
\hline \multicolumn{1}{c}{ Nội dung công việc } & $\begin{array}{c}\text { Đơn } \\
\text { vị }\end{array}$ & $\begin{array}{c}\text { Số } \\
\text { lượng }\end{array}$ \\
\cline { 2 - 2 } Tổng số lỗ khoan & Lố & 102 \\
Tống số mét khoan & Mét & 2755 \\
Thí nghiệm mẫu đất nguyên dạng & Mẫu & 706 \\
Thí nghiệm mẫu dất không nguyên dạng & Mẫu & 36 \\
Thí nghiệm cắt cánh hiện trường & Điểm 46 \\
Thí nghiệm xuyên tiêu chuẩn SPT trong hố khoan & Điểm 1130 \\
\hline
\end{tabular}

\subsection{Phuơng pháp nghiên cúu}

\subsubsection{Nhóm phưong pháp nghiên cúu ngoài trời}

- Phương pháp khảo sát địa chất - địa mạo: xác định sơ bộ đặc điểm trầm tích tại các lỗ khoan, các điểm khảo sát, kết hợp với các tài liệu khoan, đào thăm dò, thu thập các mẫu phục vụ cho công tác nghiên cứu trong phòng.

- Phương pháp khoan: tiến hành khoan xoay bơm rửa bằng ống mẫu kết hợp với lấy mẫu thí nghiệm trong phòng, thí nghiệm hiện trường xuyên tiêu chuẩn $\mathrm{SPT}$, thí nghiệm cắt cánh trong hố khoan, nhằm phục vụ cho nghiên cứu địa tầng, đặc điểm trầm tích, các quá trình và hiện tượng địa chất liên quan đến thành tạo đất yếu trầm tích Holocen khu vực nghiên cứu. Sử dụng máy khoan không tự hành XY-1, XY-4A-1 kết hợp với hệ thống phao và xà lan 400T phục vụ trong quá trình khoan khảo sát trên cạn và trên biển.

\subsubsection{Nhóm phương pháp nghiên cưu trong phòng}

- Phương pháp phân tích độ hạt trầm tích: mục đích của phương pháp là xác định phần trăm trọng lượng các cấp hạt cấu tạo nên trầm tích $(\mathrm{P})$, qua đó, xác định các thông số như kích thước hạt trung bình $(\mathrm{Md})$, độ chọn lọc (So), hệ số bất đối xứng $\left(\mathrm{S}_{\mathrm{k}}\right)$. Trong nghiên cứu này, sử dụng thang phân cấp hạt của Krumbein và Folk; đối với phương pháp rây, sử dụng với cấp hạt có đường kính $\mathrm{D} \geq$ 0,063mm; đối với phương pháp pipet, sử dụng với cấp hạt có đường kính $\mathrm{D}<0,063 \mathrm{~mm}$. Trên cơ sở hàm lượng phần trăm các cấp hạt sạn, cát, bùn phân chia các kiểu trầm tích Holocen theo phân loại của Folk, 1954.

- Phương pháp thí nghiệm các chỉ tiêu cơ lý mẫu đất: nhiệm vụ của phương pháp là xác định các chỉ tiêu cơ lý đất theo tiêu chuẩn Việt Nam, từ đó cho phép đánh giá mức độ đồng nhất và biến đổi của các đặc trưng, tính chất cơ lý của đất, góp phần phân chia chi tiết và chính xác địa tầng nghiên cứu. Các chỉ tiêu xác định, như dung trọng tự nhiên $\gamma_{\mathrm{w}}$ $\left(\mathrm{g} / \mathrm{cm}^{3}\right)$, độ ẩm tự nhiên $\mathrm{W}(\%)$, độ ẩm giới hạn chảy (Casangrande), giới hạn dẻo, góc ma sát $\varphi$ (độ), lực dính kết $\mathrm{C}\left(\mathrm{kG} / \mathrm{cm}^{2}\right)$ và một số chỉ tiêu khác.

- Phương pháp phân tích tướng trầm tích: Bản chất của phương pháp là trên cơ sở tổ hợp tướng, dựa vào các đặc điểm về cấu trúc, kiến trúc trầm tích cũng như các đặc điểm về màu sắc, tính phân lớp, đặc điểm độ hạt, sự phân bố các di tích động thực vật cùng với các dấu hiệu về điều kiện động lực, thành phần khoáng vật, các chỉ số địa hóa môi trường để nghiên cứu và phân chia các tướng trầm tích.

- Phương pháp thống kê: Sử dụng phương pháp thống kê để tổng hợp các số liệu thu thập được, tính toán phân tích sự biến đổi của các yếu tố, chỉ tiêu cơ lý hoặc các tính chất trầm tích, tìm ra quy luật biến đổi, từ đó có thể dự đoán các quá trình, hiện tượng địa chất có thể xảy ra.

\section{Kết quả nghiên cứu}

Trong khu vực nghiên cứu, trên cơ sở tổng hợp, xử lý các tài liệu địa chất, kết quả phân tích trong phòng đã xác lập 08 tướng và phụ tướng trầm tích Holocen (hình 3 ), tương ứng với 08 đơn nguyên địa chất công trình (trong đó 1 đơn nguyên tồn tại dưới dạng thấu kính thuộc tướng cát lạch triều) (bảng 2). 
Tạp chí Các Khoa học về Trái Đất, 38 (1), 108-117
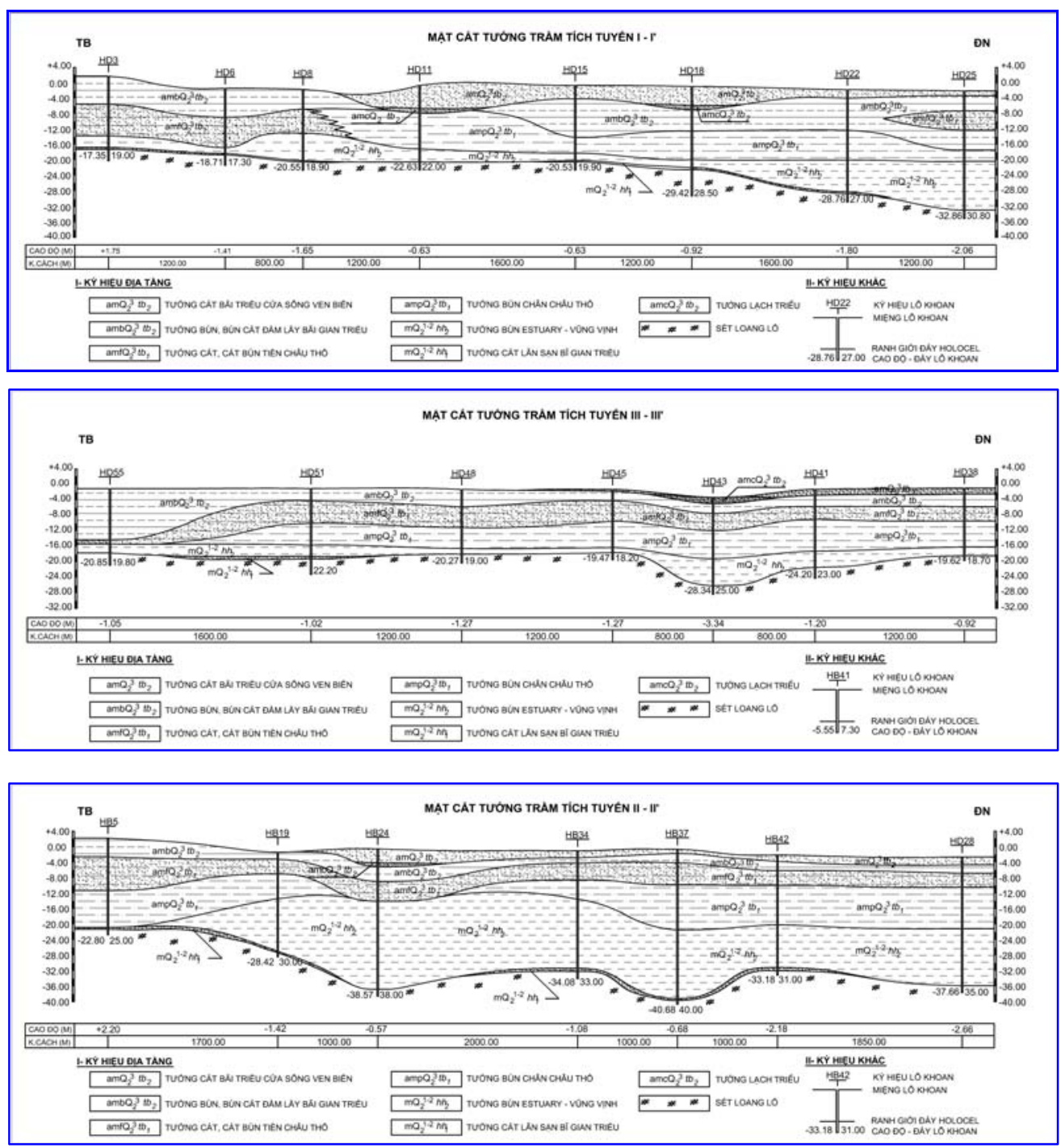

Hình 3. Các mặt cắt địa chất tiêu biểu khu vực nghiên cứu

Bảng 2. Tương quan tướng trầm tích và địa chất công trình các thành tạo Holocen

\begin{tabular}{|c|c|c|c|c|}
\hline Tuối & Hệ tầng & Ký hiệu & Tướng trầm tích & Loại đất và trạng thái \\
\hline \multirow{7}{*}{ Holocen } & \multirow{5}{*}{ Thái Bình $\left(\mathrm{Q}_{2}{ }^{3} t b\right)$} & $\mathrm{amQ}_{2}^{3} t b_{2}$ & Cát bãi triều cửa sông ven biển & Cát hạt mịn, màu xám nâu, xám; kết cấu xốp \\
\hline & & $\mathrm{amcQ}_{2}{ }^{3} t b_{2}$ & Cát lạch triều & Cát hạt trung, màu xám; kết cấu xốp \\
\hline & & $\mathrm{ambQ}_{2}{ }^{3} t b_{2}$ & Bùn đầm lầy bãi gian triều & Bùn sét, màu xám, xám nâu; trạng thái chảy \\
\hline & & $b_{l}$ & Bùn cát đâm lây bãi gian triêu & Bùn sét pha, màu xám, xám nâu; trạng thái chảy \\
\hline & & $\operatorname{ampQ}_{2}{ }^{3} t b_{1}$ & Bùn chân châu thổ (Pro delta) & Bùn sét, màu xám, xám nâu ở phía trên, \\
\hline & \multirow{2}{*}{ Hải Hưng $\left(\mathrm{Q}_{2}{ }^{1-2} h h\right)$} & $\mathrm{mQ}_{2}{ }^{1-2} h h_{2}$ & Bùn Estuary - vũng vịnh & $\begin{array}{l}\text { Sét, màu xám nhạt, xám xanh; trạng thái dẻo } \\
\text { chảy }\end{array}$ \\
\hline & & $\mathrm{mQ}_{2}{ }^{1-2} h h_{l}$ & Cát lẫn sạn bãi triều & $\begin{array}{l}\text { Cát lẫn sạn, màu nâu vàng, vàng nhạt; kết cấu } \\
\text { chặt vừa }\end{array}$ \\
\hline
\end{tabular}


V.V. Lợi/Tạp chí Các Khoa học về Trái Đất, Tập 38 (2016)

Bảng 3. Tổng hợp các chỉ tiêu cơ lý trầm tích Holocen vùng ven biển Tiên Lãng

\begin{tabular}{|c|c|c|c|c|c|c|c|c|c|}
\hline \multirow{5}{*}{ Các chỉ tiêu } & \multirow{5}{*}{ Đơn vị } & \multicolumn{8}{|c|}{ Tướng trầm tích Holocen } \\
\hline & & \multicolumn{6}{|c|}{ Holocen trên $\left(\mathrm{Q}_{2}{ }^{3}\right)$} & \multicolumn{2}{|c|}{$\begin{array}{l}\text { Holocen dưới-giữa } \\
\left(\mathrm{Q}_{2}{ }^{1-2}\right)\end{array}$} \\
\hline & & $\mathrm{amQ}_{2}{ }^{3} t b_{2}$ & $\mathrm{amcQ}_{2}{ }^{3} t b_{2}$ & $-\mathrm{ambQ}_{2}{ }^{3}$ & & $\mathrm{amfQ}_{2}{ }^{3} t b_{1}$ & $\mathrm{ampQ}_{2}{ }^{3} t b_{1}$ & $\mathrm{mQ}_{2}{ }^{1-2} h h_{2}$ & $\mathrm{mQ}_{2}{ }^{1-2} h h_{1}$ \\
\hline & & \multirow{2}{*}{$\begin{array}{l}\text { Cát bãi triều } \\
\text { cửa sông } \\
\text { ven biển }\end{array}$} & \multirow{2}{*}{$\begin{array}{l}\text { Cát lạch } \\
\text { triều }\end{array}$} & \multicolumn{2}{|c|}{$\begin{array}{c}\text { Bùn, bùn cát đầm lầy } \\
\text { bãi gian triều }\end{array}$} & \multirow{2}{*}{$\begin{array}{l}\text { Cát, cát bùn } \\
\text { tiền châu } \\
\text { thổ }\end{array}$} & \multirow{2}{*}{$\begin{array}{l}\text { Sét bùn } \\
\text { chân châu } \\
\text { thổ }\end{array}$} & \multirow{2}{*}{$\begin{array}{c}\text { Bùn sét } \\
\text { estuary- } \\
\text { vũng vịnh }\end{array}$} & \multirow{2}{*}{$\begin{array}{l}\text { Cát lẫn sạn } \\
\text { bãi triều }\end{array}$} \\
\hline & & & & Bùn & Bùn cát & & & & \\
\hline Sỏi sạn & $(\%)$ & 0,0 & $\overline{0,0}$ & 0,0 & $\overline{0,0}$ & 0,0 & $\overline{0,0}$ & $\overline{0,0}$ & 15,5 \\
\hline Cát & $(\%)$ & 94,5 & 89,6 & 7,0 & 23,3 & 60,4 & 7,7 & 8,7 & 71,8 \\
\hline Bột & $(\%)$ & 5,5 & 7,6 & 52,3 & 53,5 & 32,7 & 52,5 & 53,5 & 10,7 \\
\hline Sét & $(\%)$ & 0,0 & 2,8 & 40,7 & 23,2 & 6,9 & 39,8 & 37,8 & 2,0 \\
\hline Dung trọng TN & $\begin{array}{l}\gamma \mathrm{W} \\
\left(\mathrm{g} / \mathrm{cm}^{3}\right)\end{array}$ & & & 1,63 & 1,77 & 1,88 & 1,65 & 1,72 & \\
\hline Dung trọng khô & $\begin{array}{l}\gamma \mathrm{d} \\
\left(\mathrm{g} / \mathrm{cm}^{3}\right)\end{array}$ & & & 1,037 & 1,306 & 1,524 & 1,077 & 1,191 & \\
\hline Độ ẩm tự nhiên & $\mathrm{W}(\%)$ & & & 57,14 & 35,57 & 23,33 & 53,17 & 44,44 & \\
\hline Giới hạn chảy & LL $(\%)$ & & & 52,66 & 32,76 & 21,97 & 50,95 & 48,10 & \\
\hline Giới hạn dẻo & PL(\%) & & & 28,50 & 20,10 & 16,70 & 28,14 & 25,94 & \\
\hline Chỉ số dẻo & LI(\%) & & & 24,16 & 12,66 & 5,27 & 22,81 & 22,16 & \\
\hline Độ sệt & & & & 1,19 & 1,22 & 1,26 & 1,10 & 0,83 & \\
\hline Tỷ trọng & $\Delta$ & 2,65 & 2,66 & 2,69 & 2,69 & 2,67 & 2,70 & 2,71 & 2,64 \\
\hline Hệ số rỗng & $\varepsilon_{\mathrm{o}}$ & & & 1,5940 & 1,0597 & 0,7520 & 1,5070 & 1,2754 & \\
\hline Độ rỗng & $\mathrm{n}(\%)$ & & & 61,45 & 51,45 & 42,92 & 60,11 & 56,05 & \\
\hline Độ bão hoà & $\mathrm{S}(\%)$ & & & 96,43 & 90,29 & 82,83 & 95,26 & 94,43 & \\
\hline \multirow{5}{*}{$\begin{array}{l}\text { Thí nghiệm cắt } \\
\text { trực tiếp } \\
\text { Thí nghiệm } 3 \\
\text { trục theo sơ đồ } \\
\text { UU }\end{array}$} & $\varphi$ (độ) & & & $2^{\circ} 28^{\prime}$ & $7^{\circ} 08^{\prime}$ & $15^{\circ} 49^{\prime}$ & $3^{\circ} 32^{\prime}$ & $6^{\circ} 18^{\prime}$ & \\
\hline & $\mathrm{C}\left(\mathrm{kG} / \mathrm{cm}^{2}\right)$ & & & 0,033 & 0,042 & 0,024 & 0,046 & 0,078 & \\
\hline & $\varphi_{\text {uu }}($ độ) & & & $1^{\circ} 37^{\prime}$ & $5^{\circ} 37^{\prime}$ & & $2^{\circ} 31^{\prime}$ & $4^{\circ} 51^{\prime}$ & \\
\hline & $\begin{array}{l}\mathrm{C}_{\mathrm{uu}} \\
\left(\mathrm{kG} / \mathrm{cm}^{2}\right)\end{array}$ & & & 0,049 & 0,065 & & 0,068 & 0,112 & \\
\hline & $\varphi_{\mathrm{cu}}($ độ$)$ & & & $6^{\circ} 52^{\prime}$ & $10^{\circ} 36^{\prime}$ & & $8^{\circ} 30^{\prime}$ & $11^{\circ} 11^{\prime}$ & \\
\hline \multirow{4}{*}{$\begin{array}{l}\text { Thí nghiệm } 3 \\
\text { trục theo sơ đồ } \\
\text { CU }\end{array}$} & $\begin{array}{l}\mathrm{C}_{\mathrm{cu}} \\
\left(\mathrm{kG} / \mathrm{cm}^{2}\right)\end{array}$ & & & 0,116 & 0,134 & & 0,129 & 0,170 & \\
\hline & $\varphi_{\mathrm{cu}}^{\prime}($ độ $)$ & & & $7^{\circ} 58^{\prime}$ & $12^{\circ} 19^{\prime}$ & & $10^{\circ} 15^{\prime}$ & $12^{\circ} 55^{\prime}$ & \\
\hline & $\begin{array}{l}\mathrm{C}_{\mathrm{cu}}^{\prime} \\
\left(\mathrm{kG} / \mathrm{cm}^{2}\right)\end{array}$ & & & 0,113 & 0,127 & & 0,122 & 0,161 & \\
\hline & $\begin{array}{l}\mathrm{a}_{1-2} \\
\left(\mathrm{~cm}^{2} / \mathrm{kG}\right)\end{array}$ & & & 0,102 & 0,060 & & 0,098 & 0,052 & \\
\hline \multirow[t]{3}{*}{$\begin{array}{l}\text { Thí nghiệm nén } \\
\text { cố kêt }\end{array}$} & $\begin{array}{l}\mathrm{Pc} \\
\left(\mathrm{kG} / \mathrm{cm}^{2}\right)\end{array}$ & & & 0,50 & 0,66 & & 0,55 & 0,74 & \\
\hline & $\mathrm{Cc}$ & & & 0,42 & 0,20 & & 0,36 & 0,24 & \\
\hline & Cs & & & 0,022 & 0,030 & & 0,025 & 0,031 & \\
\hline $\begin{array}{l}\text { Thí nghiệm cắt } \\
\text { cánh hiện }\end{array}$ & Sumax & & & 0,056 & 0,078 & & 0,112 & 0,124 & \\
\hline $\begin{array}{l}\text { trường } \\
\left(\mathrm{daN} / \mathrm{cm}^{2}\right)\end{array}$ & Sumin & & & 0,023 & 0,038 & & 0,042 & 0,071 & \\
\hline Góc nghỉ khô & $\alpha \mathrm{d}$ & $26^{\circ} 18^{\prime}$ & $27^{\circ} 07^{\prime}$ & & & & & & $33^{\circ} 24^{\prime}$ \\
\hline Góc nghỉ ướt & $\alpha \mathrm{w}$ & $22^{\circ} 46^{\prime}$ & $22^{\circ} 25^{\prime}$ & & & & & & $27^{\circ} 18^{\prime}$ \\
\hline
\end{tabular}

4.1. Các tướng trầm tích hệ tầng Hải Hung (Holocen duới - giũ̃a - $\mathbf{Q}_{2}{ }^{1-2}$ )

\subsubsection{Tướng cát lẫn sạn bãi triều $\left(\mathrm{mQ}_{2}{ }^{1-2} h h_{1}\right)$}

Tướng trầm tích này gặp trong một số lỗ khoan vùng nghiên cứu (HD3, HD6, HD8, HD15, HD18, HD22), phủ bất chỉnh hợp trên bề mặt tầng sét loang lổ hệ tầng Vĩnh Phúc. Bề dày thay đổi trong khoảng $0,30 \div 0,80 \mathrm{~m}$. Thành phần là cát mịn-trung, màu xám xanh lẫn sạn laterit màu nâu, nâu đỏ; kêt cấu chặt vừa. Thành phần trầm tích gồm: Sạn:
$13,2 \div 17,4 \%$, trung bình $15,5 \%$; Cát: $66,6 \div 85,4 \%$, trung bình $71,8 \%$; Bột: $8,6 \div 12,6 \%$, trung bình $10,7 \%$; Sét: $1,4 \div 3,6 \%$, trung bình $2,0 \%$. Thông số độ hạt: $\mathrm{Md}: 0,22 \div 0,28 \mathrm{~mm}$; So: $1,42 \div 1,71$; Sk: $1,5 \div 1,34$.

Tướng trầm tích này tương ứng với lớp cát mịn lẫn ít sạn, kết cấu chặt vừa theo phân loại đất trong địa chất công trình. Thí nghiệm SPT cho $\mathrm{N}_{30}=$ $13 \div 17$ búa $/ 30 \mathrm{~cm}$. Một số chỉ tiêu vật lý: Khối lượng riêng (tỷ trọng): $2,63 \div 2.64 \mathrm{~g} / \mathrm{cm}^{3}$, trung bình 
Tạp chí Các Khoa học về Trái Đất, 38 (1), 108-117

2,64; Góc nghỉ khi khô: $32^{\circ} 18^{\prime} \div 33^{\circ} 47^{\prime}$, trung bình $33^{\circ} 24^{\prime}$; Góc nghỉ khi ướt: $26^{\circ} 21^{\prime} \div 27^{\circ} 42^{\prime}$, trung bình $27^{\circ} 18^{\prime}$.

\subsubsection{Tướng bùn sét estuary - vũng vịnh $\left(m Q_{2}{ }^{1-2}\right.$ $\left.h h_{2}\right)$}

Trên mặt cắt địa chất (hình 3 ) cho thấy trầm tích này phân bố khá đồng đều trên toàn bộ khu vực nghiên cứu với thành phần chủ yếu là bùn màu xám, xám xanh đồng nhất, lẫn hợp chất hữu cơ phân hủy, phân bố từ độ sâu $11,40 \mathrm{~m}$ đến $38,50 \mathrm{~m}$. Trầm tích có cấu tạo phân lớp song song dạng phân dải xen kẹp các thấu kính cát mịn mỏng. Thành phần trầm tích gồm cát: $6,4 \div 11,5 \%$, trung bình $8,7 \%$; Bột: $47,8 \div 54,3 \%$, trung bình 53,5\%; Sét: $34,5 \div 41,8 \%$, trung bình $37,8 \%$. Thông số độ hạt: Md: $0,0064 \div 0,0082 \mathrm{~mm}$; So: $2,76 \div 3,42$; Sk: $0,87 \div 1,28$. Hàm lượng khoáng vật sét: kaolinit: $20 \div 35 \%$, hydromica: $25 \div 30 \%$, montmorilonit: $25 \div 40 \%$. Các chỉ số địa hóa môi trường trầm tích:

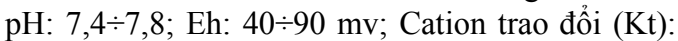
$1,4 \div 1,9 ; \mathrm{Fe}^{2+} \mathrm{S} /$ Corg: $0,3 \div 0,5$. Trầm tích chứa bào tử phấn hoa: Acrostichum sp., Polypodium sp., Pteris sp., Taxus sp., Pinus sp., Tsuga sp.,... Bề dày trầm tích giảm dần từ trung tâm vùng nghiên cứu về hai cửa sông phía Thái Bình và Văn Úc, trung bình đạt $6,14 \mathrm{~m}$.

Tướng trầm tích này tương ứng với lớp sét trạng thái dẻo chảy theo phân loại đất trong địa chất công trình. Thí nghiệm SPT cho $\mathrm{N}_{30}=3 \div 6$ búa/30 cm. Một số chỉ tiêu cơ lý: Độ ẩm: 40,98 $\div 50,06 \%$, trung bình 44,44\%; Dung trọng tự nhiên: $1,67 \div 1,77 \mathrm{~g} / \mathrm{cm}^{3}$, trung bình $1,72 \mathrm{~g} / \mathrm{cm}^{3} ; \varphi_{\text {uu }}$ $=3^{\circ} 20^{\prime} \div 4^{\circ} 37^{\prime}$, trung bình $\varphi_{\mathrm{uu}}=4^{\circ} 51^{\prime} ; \mathrm{C}_{\mathrm{uu}}=$ $0,106 \div 0,117 \mathrm{kG} / \mathrm{cm}^{2}$, trung bình $\mathrm{C}_{\mathrm{uu}}=0,112$ $\mathrm{kG} / \mathrm{cm}^{2}$ (bảng 3 ).

\subsection{Các tuớng trầm tích hệ tầng Thái Bình (Holocen trên- $Q_{2}{ }^{3}$ )}

\subsubsection{Tướng sét bùn chân châu thổ ( $\left.\operatorname{amp} Q_{2}{ }^{3} t b_{1}\right)$}

Tướng trầm tích này bắt gặp trong hầu hết các 1ỗ khoan vùng nghiên cứu. Trầm tích có màu xám, xám nâu ở phía trên, chuyển dần sang màu xám, xám nhạt xuống phía dưới, cấu tạo phân lớp ngang song song. Thành phần trầm tích gồm Cát: $4,8 \div 10,7 \%$, trung bình 7,7\%; Bột: 48,6 $\div 56,2 \%$, trung bình 52,5\%; Sét: $35,5 \div 43,3 \%$, trung bình $39,8 \%$. Hàm lượng bột và cát tăng dần từ dưới lên.
Thông số độ hạt: Md: 0,006 $\div 0,009 \mathrm{~mm}$; So: $2,97 \div 3,52$; Sk: $0,75 \div 0,82$. Hàm lượng khoáng vật sét trong trầm tích: kaolinit: $15 \div 20 \%$, hydromica: $20 \div 25 \%$, montmorilonit: $35 \div 45 \%$. Các chỉ số địa hóa môi trường: $\mathrm{pH}: 7,6 \div 8,4$; Eh: $50 \div 90 \mathrm{mv}$; Cation trao đổi $(\mathrm{Kt}): 1,5 \div 1,8 ; \mathrm{Fe}^{2+} \mathrm{S} / \mathrm{Corg}: 0,3 \div 0,5$. Trầm tích chứa Foraminifera: Quinqueloculina sp., Elphidium sp., E. hispidulum, Ammonia beccarri, Pseudorotalia schroeteriana, P. indopacific (Doãn Đình Lâm, 2003). Bề dày trung bình đạt $6,02 \mathrm{~m}$.

Tướng trầm tích này tương ứng với lớp bùn sét, trạng thái chảy theo phân loại đất trong địa chất công trình. Thí nghiệm SPT cho $\mathrm{N}_{30}=1 \div 3$ búa $/ 30 \mathrm{~cm}$. Một số chỉ tiêu cơ lý: Độ ẩm: $50,68 \div 55,78 \%$, trung bình $53,17 \%$; Dung trọng tự nhiên: $1,62 \div 1,68 \mathrm{~g} / \mathrm{cm}^{3}$, trung bình $1,65 \mathrm{~g} / \mathrm{cm}^{3} ; \varphi_{\text {uu }}$ $=2^{\circ} 09^{\prime} \div 3^{\circ} 08^{\prime}$, trung bình $\varphi_{\text {uu }}=2^{\circ} 31^{\prime} ; \mathrm{C}_{\mathrm{uu}}=$ $0,061 \div 0,077 \mathrm{kG} / \mathrm{cm}^{2}$, trung bình $\mathrm{C}_{\mathrm{uu}}=0,068$ $\mathrm{kG} / \mathrm{cm}^{2}$ (bảng 2).

4.2.2. Tướng cát, cát bùn tiền châu thổ $\left(\mathrm{amfQ}_{2}{ }^{3}\right.$ $\left.t b_{1}\right)$

Tướng trầm tích gặp trong hầu hết các lỗ khoan khu vực nghiên cứu, đôi khi lộ ra trên bề mặt; phân bố chủ yếu ở giữa khu vực nghiên cứu và giảm dần về hai phía cửa sông, đặc biệt giảm mạnh về phía cửa sông Thái Bình. Trầm tích có cấu trúc phân lớp xiên thoải, xen kẹp giữa các lớp cát mịn là các lớp cát bùn, bột sét mỏng. Thành phần trầm tích gồm cát mịn: $55,8 \div 70,5 \%$, trung bình $60,4 \%$; Bột: $23,8 \div 37,3 \%$, trung bình $32,7 \%$; Sét: $3,5 \div 11,6 \%$, trung bình $6,9 \%$. Trầm tích có độ chọn lọc trung bình So: $1,9 \div 2,5$; kích thước hạt trung bình $(\mathrm{Md})$ : $0,21 \div 0,26 \mathrm{~mm}$. Hàm lượng khoáng vật sét trong phần sét gồm: kaolinit: $20 \div 25 \%$, hydromica: $25 \div 30 \%$, montmorilonit: $25 \div 35 \%$. Các chỉ số địa

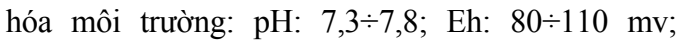
Cation trao đổi $(\mathrm{Kt})$ : $1,2 \div 1,5$; trị số $\mathrm{Fe}^{2+} \mathrm{S} / \mathrm{Corg}$ : $0,1 \div 0,4$. Trầm tích chứa Foraminifera: Quinqueloculina sp., Elphidium sp., Ammonia beccarri, Ammonia advenum, Spiroloculina sp. Bề dày trung bình $4,51 \mathrm{~m}$.

Tướng trầm tích này tương ứng với lớp cát, cát pha kết cấu xốp theo phân loại đất trong địa chất công trình; Thí nghiệm SPT cho $\mathrm{N}_{30}=4 \div 8$ búa $/ 30 \mathrm{~cm}$, đôi chỗ $\mathrm{N}_{30}=12$ (búa $\left./ 30 \mathrm{~cm}\right)$. Một số chỉ tiêu cơ lý gồm: Độ ẩm: 19,56 $\div 24,14 \%$, trung bình $23,33 \%$; Dung trọng tự nhiên: $1,82 \div 1,94$ 
V.V. Lợi/Tạp chí Các Khoa học về Trái Đất, Tập 38 (2016)

$\mathrm{g} / \mathrm{cm}^{3}$, trung bình $1,88 \mathrm{~g} / \mathrm{cm}^{3} ; \varphi=14^{\circ} 34^{\prime} \div 16^{\circ} 44^{\prime}$, trung bình $\varphi=15^{\circ} 49^{\prime} ; \mathrm{C}=0,021 \div 0,028 \mathrm{kG} / \mathrm{cm}^{2}$, trung bình $\mathrm{C}_{\mathrm{uu}}=0,024 \mathrm{kG} / \mathrm{cm}^{2}$ (bảng 3 ).

4.2.3. Tướng bùn, bùn cát đầm lầy bãi gian triều $\left(\mathrm{ambQ}_{2}{ }^{3} t b_{2}\right)$

Trầm tích bùn, bùn cát đầm lầy bãi gian triều phân bố chủ yếu ở khu vực phía tây bắc vùng nghiên cứu, với khoảng cách từ đê quốc gia ra phía biển khoảng $2,5 \mathrm{~km}$, nơi có rừng ngập mặn và hệ thống đầm nuôi thủy sản phát triển. Trên cở sở đặc điểm phân bố, có thể phân chia hai phụ tướng theo thành phần độ hạt: $\left.t b_{2}\right)$

Phu tướng bùn đầm lầy bãi gian triều $\left(a m b Q_{2}{ }^{3}\right.$

Trong vùng nghiên cứu, trầm tích này phân bố tương đối đều tại khu vực bãi triều cao, xuất hiện ngay trên mặt địa hình bãi với chiều dày đạt đến $11,80 \mathrm{~m}$ tại khu vực cửa sông Văn Úc, giảm dần theo hướng ra biển và về phía cửa sông Thái Bình với bề dày nhỏ nhất $0,80 \mathrm{~m}$, trung bình $3,38 \mathrm{~m}$. Trầm tích có màu xám đen nhạt, xám nâu đôi chỗ xám tối, xen kẹp các dải cát hạt mịn phân lớp mỏng, dạng hạt đậu (bề dày $0,05 \div 0,15 \mathrm{~m}$ ), chứa mùn bã thực vật màu đen. Thành phần trầm tích gồm Cát: $5,4 \div 11,2 \%$, trung bình 7,0\%; Bột: $51,8 \div$ $55,6 \%$, trung bình $52,3 \%$; Sét: $37,8 \div 42,4 \%$, trung bình $40,7 \%$.

Phụ tướng này tương ứng với lớp bùn sét, trạng thái chảy theo phân loại đất trong địa chất công trình. Thí nghiệm SPT cho $0<\mathrm{N}_{30} \leq 3$ búa $/ 30 \mathrm{~cm}$. Một số chỉ tiêu cơ lý: Độ ẩm: 54,20 $63,55 \%$, trung bình 57,14\%; Dung trọng tự nhiên: 1,58 $\div 1,64$ $\mathrm{g} / \mathrm{cm}^{3}$, trung bình $1,63 \mathrm{~g} / \mathrm{cm}^{3} ; \varphi_{\text {uu }}=1^{\circ} 12^{\prime} \div 1^{\circ} 44^{\prime}$, trung bình $\varphi_{\mathrm{uu}}=1^{\circ} 37^{\prime} ; \mathrm{C}_{\mathrm{uu}}=0,046 \div 0,052 \mathrm{kG} / \mathrm{cm}^{2}$, trung bình $\mathrm{C}_{\mathrm{uu}}=0,049 \mathrm{kG} / \mathrm{cm}^{2}$ (bảng 3).

Phụ tướng bùn cát đầm lầy bãi gian triều $\left(a m b Q_{2}^{3} t b_{2}\right)$

Phụ tướng này phân bố chủ yếu khu vực cửa sông Thái Bình với chiều dày $4,69 \mathrm{~m}$, giảm dần về phía cửa sông Văn Úc, trầm tích có màu xám, xám nâu, đôi chỗ xám đen, xen kẹp nhiều dải cát hạt mịn màu xám nâu phân lớp mỏng (dày $0,05 \div 0,18 \mathrm{~m})$, nhiều chỗ gần như là bùn cát, cát, cát bùn lẫn vỏ sò và hợp chất hữu cơ phân hủy màu đen. Thành phần trầm tích gồm: Cát mịn: $18,6 \div 26,5 \%$, trung bình 23,3\%; Bột: 49,8 $\div 55,3 \%$, trung bình $53,5 \%$; Sét: $14,7 \div 26,4 \%$, trung bình $23,3 \%$.

Phụ tướng này tương ứng với lớp bùn sét pha, trạng thái chảy theo phân loại đất trong địa chất công trình. Thí nghiệm SPT cho $\mathrm{N}_{30}=1 \div 5$ búa $/ 30 \mathrm{~cm}$. Một số chỉ tiêu cơ lý: Độ ẩm: $28,36 \div 42,11 \%$, trung bình $35,70 \%$; Dung trọng tự nhiên: $1,70 \div 1,84\left(\mathrm{~g} / \mathrm{cm}^{3}\right)$, trung bình $1,77 \mathrm{~g} / \mathrm{cm}^{3}$; $\varphi_{\mathrm{uu}}=4^{\mathrm{o}} 18^{\prime} \div 6^{\mathrm{o}} 28^{\prime}$, trung bình $\varphi_{\mathrm{uu}}=5^{\circ} 37^{\prime} ; \mathrm{C}_{\mathrm{uu}}=$ $0,060 \div 0,068 \mathrm{kG} / \mathrm{cm}^{2}$, trung bình $\mathrm{C}_{\mathrm{uu}}=0,065$ $\mathrm{kG} / \mathrm{cm}^{2}$ (bảng 3 ).

Hàm lượng khoáng vật sét: kaolinit: $40 \div 45 \%$, hydromica: $20 \div 35 \%$, montmorilonit: $15 \div 20 \%$. Các chỉ số địa hóa môi trường: $\mathrm{pH}: 7,2 \div 7,5$; Eh: $40 \div 10 \mathrm{mv}$; Kt: $0,7 \div 0,8 ; \mathrm{Fe}^{2+} \mathrm{S} /$ Corg: $0,08 \div 0,15$. Trầm tích chứa tổ hợp Diatomeae lợ-mặn đặc trưng gồm: Caloneis formosa, Caloneis sp., Coscinodiscus lacustris, Cyclotella striata, Diploneis smithii,... Bào tử phấn bao có mặt trong trầm tích gồm: Phragmite eriopoda, Paspadum vaginatum, Cynodon dactylon, Hibiscus sp., Cyperus sp., Ipomoea maritime,... (Doãn Đình Lâm, 2003)

\subsubsection{Tướng cát lạch triều $\left(\mathrm{amcQ}_{2}{ }^{3} t b_{2}\right)$}

Tướng trầm tích cát lạch triều bắt gặp hạn chế trong một số lỗ khoan như HD11, HD18, HB24 và lộ ra trên bề mặt tại vị trí lỗ khoan HD 43. Trầm tích có thành phần chủ yếu là cát hạt trung, màu xám, cấu tạo xiên chéo đặc trưng cho thành tạo của lạch triều. Tướng trầm tích cát lạch triều bị phủ trên hoặc chuyển tướng ngang với tướng cát bãi triều. Hàm lượng thạch anh từ $60-70$ đến $80-85 \%$, mảnh đá từ 15 đến $20 \%$ (Doãn Đình Lâm, 2003). Kích thước hạt trung bình $(\mathrm{Md}): 0,15 \div 0,45 \mathrm{~mm}$, hệ số chọn lọc (So): 1,6 $\div 2,5$. Do hoạt động mạnh mẽ của triều nên trầm tích tướng lạch triều khá nghèo nàn di tích bào tử phấn hoa và vi cổ sinh. Tướng trầm tích này tương ứng với thấu kính cát hạt trung, kết cấu xốp. Khi phân chia đơn nguyên địa chất công trình thì lớp này tồn tại dưới dạng thấu kính, chiều dày từ $1,5 \mathrm{~m}$ đến $2,2 \mathrm{~m}$ (bảng 3 ).

4.2.5. Tuớng cát bãi triều cửa sông ven biển $\left(\mathrm{amQ}_{2}{ }^{3} t b_{2}\right)$

Tướng trầm tích này bắt gặp phần lớn trong khu vực nghiên cứu, phân bố chủ yếu ở khu vực bãi triều thấp và tập trung khu vực giữa vùng nghiên cứu và hướng ra biển. Trầm tích có màu 
xám nâu, xám, xen kẹp các dải bùn, bùn cát mỏng (dày $0,05 \div 0,20 \mathrm{~m}$ ). Bề dày trung bình $1,56 \mathrm{~m}$. Thành phần trầm tích gồm: Cát: $90,5 \div 95,5 \%$, trung bình $94,5 \%$; Bột: $2,2 \div 9,5 \%$, trung bình 4,5\%. Kích thước hạt trung bình (Md): $0,21 \div 0,28 \mathrm{~mm}$; hệ

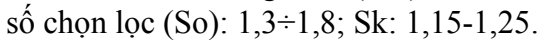

Tướng trầm tích này tương ứng với lớp cát hạt mịn theo phân loại đất trong địa chất công trình; kết cấu xốp. Thí nghiệm SPT N30= $3 \div 5$ búa $/ 30 \mathrm{~cm}$. Một số chỉ tiêu cơ lý: khối lượng riêng (tỷ trọng): $2,64 \div 2,66 \mathrm{~g} / \mathrm{cm}^{3}$, trung bình 2,65 ; Góc nghỉ khi khô: $25^{\circ} 44^{\prime} \div 27^{\circ} 17^{\prime}$, trung bình $26^{\circ} 18^{\prime}$; Góc nghỉ khi ướt: $22^{\circ} 11^{\prime} \div 23^{\circ} 34^{\prime}$, trung bình $22^{\circ} 46^{\prime}$ (bảng 3 ).

\section{3. Đặc điểm phân bố các thành tạo Holocen khu vục ven biển h. Tiên Lãng}

4.3.1. Các tướng trầm tích Holocen duoói - giũa $\left(\mathrm{Q}_{2}{ }^{1-2}\right)$

Gồm trầm tích cát lẫn sạn bãi triều và trầm tích bùn sét estuary - vũng vịnh. Các tướng trầm tích này phân bố tương đối phổ biến khu vực nghiên cứu, chiều sâu từ $11,40 \mathrm{~m}$ đến $39,00 \mathrm{~m}$, bề dày từ $0,50 \mathrm{~m}$ đến $22,70 \mathrm{~m}$, dày nhất ở trung tâm khu vực nghiên cứu và giảm dần về hai hướng đông bắc và tây nam. Các trầm tích này có trị số thí nghiệm xuyên tiêu chuẩn SPT thay đổi từ $\mathrm{N}_{30}=3 \div 17$ búa $/ 30 \mathrm{~cm}$; tính nén lún lớn, không đều; áp lực tiền cố kết $\left(\mathrm{Pc}=0,74 \mathrm{kG} / \mathrm{cm}^{2}\right)$ và độ bền kháng cắt $\left(\varphi_{\mathrm{uu}}\right.$ $=4^{\circ} 51^{\prime} ; \mathrm{C}_{\mathrm{uu}}=0,112 \mathrm{kG} / \mathrm{cm}^{2}$ ) nhỏ, có hướng tăng dần theo chiều sâu.

\subsubsection{Các tướng trầm tích Holocen muộn $\left(\mathrm{Q}_{2}{ }^{3}\right)$}

Gồm tướng bùn chân châu thổ, tướng cát, cát bùn tiền châu thổ, tướng bùn cát đầm lầy bãi gian triều, tướng cát lạch triều và tướng cát bãi triều. Tướng bùn chân châu thổ phân bố trên khắp khu vực nghiên cứu, bề dày trung bình $6,02 \mathrm{~m}$. Tướng cát, cát bùn tiền châu thổ phân bố chủ yếu ở trung tâm khu vực nghiên cứu với bề dày lớn nhất và giảm dần về hai phía cửa sông Văn Úc và sông Thái Bình, bề dày trung bình $4,51 \mathrm{~m}$. Tướng bùn cát đầm lầy bãi gian triều phân bố phổ biến trong khu vực bãi triều cao, lộ ra ngay trên bề mặt với bề dày từ $0,80 \mathrm{~m}$ đến $11,80 \mathrm{~m}$, giảm dần theo hướng $\mathrm{ra}$ biển và sông Thái Bình. Tướng bùn cát bãi gian triều phân bố chủ yếu ở khu vực cửa sông Thái Bình với chiều dày $4,69 \mathrm{~m}$, giảm dần về phía cửa sông Văn Úc. Tướng cát lạch triều gặp khu vực cửa sông Văn Úc và sông Thái Bình và hạn chế trong khu vực nghiên cứu, chiều dày từ 1,5 đến $2,2 \mathrm{~m}$. Tướng trầm tích cát bãi triều cửa sông ven biển phân bố tập trung chủ yếu ở khu vực bãi triều thấp, khu vực trung tâm vùng nghiên cứu và hướng ra biển, chiều dày $1,56 \mathrm{~m}$. Các tướng trầm tích Holocen trên $\left(\mathrm{Q}_{2}{ }^{3}\right)$ có tính nén lún lớn, không đều; trị số thí nghiệm xuyên tiêu chuẩn SPT thấp $\left(\mathrm{N}_{30}=\right.$ $0 \div 8$ búa $/ 30 \mathrm{~cm})$, áp lực tiền cố kết $(\mathrm{Pc}=0,50 \div 0,60$ $\left.\mathrm{kG} / \mathrm{cm}^{2}\right)$ và độ bền kháng cắt $\left(\varphi_{\mathrm{uu}}=1^{\circ} 37^{\prime} \div 5^{\circ} 37^{\prime}\right.$; $\mathrm{C}_{\mathrm{uu}}=0,049 \div 0,068 \mathrm{kG} / \mathrm{cm}^{2}$ ) nhỏ, có hướng tăng dần theo chiều sâu.

\subsubsection{Tưong quan tuoóng trầm tích và địa chất công trình}

Kết quả nghiên cứu đặc điểm tướng trầm tích và địa chất công trình các thành tạo Holocen khu vực ven biển huyện Tiên Lãng, thành phố Hải Phòng, đã xác định được 8 tướng và phụ tướng trầm tích Holocen, tương ứng với 8 đơn nguyên địa chất công trình, chúng có mối tương quan chặt chẽ với nhau (bảng 2).

So sánh đặc điểm địa chất công trình của các tướng trầm tích có thể thấy, tướng cát sạn bãi triều Holocen sớm - giữa thuộc hệ tầng Hải Hưng với tuổi cổ hơn có kết cấu chặt vừa, trong khi tướng cát bãi triều Holocen muộn thuộc hệ tầng Thái Bình có kết cấu xốp. Tương tự, tướng bùn Estuary - vũng vịnh tuổi Holocen sớm - giữa ở trạng thái dẻo chảy đôi chỗ dẻo mềm trong khi các tướng bùn đầm lầy bãi gian triều Holocen muộn (có tuổi trẻ) hơn ở trạng thái chảy. Trong các thành tạo Holocen muộn, các tướng tiền châu thổ và bãi triều có thành phần hạt trung, đất yếu; trong khi các tướng đầm lầy, chân châu thổ có thành phần hạt mịn, đất rất yếu.

\section{Kết luận}

Từ các kết quả trình bày ở trên, một số kết luận được rút ra như sau:

(i) Trên cơ sở nghiên cứu đặc điểm tướng trầm tích và địa chất công trình, trong khu vực ven biển huyện Tiên Lãng, thành phố Hải Phòng có mặt 8 tướng và phụ tướng trầm tích Holocen với các đặc trưng về địa chất công trình gồm: tướng cát lẫn sạn bãi triều, tướng bùn sét estuary - vũng vịnh, tướng sét bùn chân châu thổ, tướng cát-cát bùn tiền châu 
V.V. Lợi/Tạp chí Các Khoa học về Trái Đất, Tập 38 (2016)

thổ, phụ tướng bùn đầm lầy bãi gian triều, phụ tướng bùn cát đầm lầy bãi gian triều, tướng cát lạch triều và tướng cát bãi triều cửa sông ven biển.

(ii) Các tướng trầm tích Holocen thể hiện rõ tính qui luật phân bố theo chiều ngang và chiều dọc trong khu vực nghiên cứu. Chiều dày trầm tích có xu hướng tăng dần từ khu vực tuyến giữa vùng nghiên cứu hướng ra biển và giảm dần về phía hai cửa sông Văn Úc và cửa sông Thái Bình.

(iii) Các loại đất của thành tạo Holocen trong khu vực nghiên cứu có các chỉ tiêu cơ lý cho thấy đất có tính nén lún lớn và không đều, độ bền kiến trúc nhỏ, đất rất yếu. Đất thuộc nhóm tướng cát, cát-cát bùn của hệ tầng Thái Bình yếu hơn so với đất thuộc tướng cát lẫn sạn bãi triều của hệ tầng Hải Hưng, với các trị số xuyên tiêu chuẩn SPT nhỏ và có hướng tăng dần theo chiều sâu. Đối với đất thuộc nhóm tướng còn lại hệ tầng Thái Bình yếu hơn so với đất thuộc tướng bùn estuary - vũng vịnh của hệ tầng Hải Hưng, đặc biệt là phụ tướng bùn đầm lầy bãi gian triều thuộc hệ tầng Thái Bình, với trị số xuyên tiêu chuẩn SPT rất nhỏ, độ ẩm rất cao, đất rất yếu. Với đặc tính quan trọng của đất yếu, đây là một trong những nguyên nhân gây ra tai biến địa chất khi xây dựng công trình, vì vậy, khi thiết kế quy hoạch cần đặc biệt quan tâm đến các thành tạo đất yếu của trầm tích Holocen.

\section{Lời cảm ơn}

Nghiên cứu này được tài trợ bởi Qũy Phát triển Khoa học và Công nghệ Quốc gia (NAFOSTED) trong đề tài mã số 105.99-2012.14.

\section{Tài liệu dẫn}

Nguyễn Đức Cự, 2011: Báo cáo đánh giá tác động thủy thành động lực phục vụ lập dự án tuyến quai đê lấn biển huyện Tiên Lãng, thành phố Hải Phòng, tr.27-68.

Nguyễn Đức Đại, 1996: Báo cáo điều tra địa chất đô thị thành phố Hải Phòng, tr.45-57.

Nguyen Xuan Hien, Dinh Van Uu, Tran Thuc, Pham Van Tien, 2010: Study on wave setup with the storm surge in Hai Phong coastal and estuarine region. VNU Journal of Science, Earth Sciences 26, pp.82-89.

Doãn Đình Lâm, 2003: Lịch sử tiến hóa trầm tích Holocen châu thổ Sông Hồng. Luận án Tiến sĩ Địa chất, Đại học Quốc gia Hà Nội. Lưu trữ tại Thư viện Viện Địa chất.

Hoang Trung Thanh, Pham Van Huan, 2009: Extreme values and rising tendencies of sea levels along Vietnam coast. VNU Journal of Science, Earth Sciences 25, pp.116-124.

Ngô Quang Toàn, 1995: Đặc điểm trầm tích và lịch sử phát triển các thành tạo Đệ tứ ở phần Đông Bắc đồng bằng Sông Hồng. Luận án Phó tiến sỹ Địa lý - Địa chất, Đại học Tổng hợp Hà Nội. 